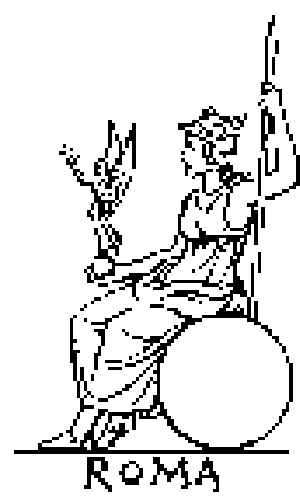

A Determining Factor in the Development of Roman Architecture

Author(s): A. W. Van Buren

Source: The Journal of Roman Studies, Vol. 1 (1911), pp. 196-198

Published by: Society for the Promotion of Roman Studies

Stable URL: http://www.jstor.org/stable/295865

Accessed: 17/06/2014 01:24

Your use of the JSTOR archive indicates your acceptance of the Terms \& Conditions of Use, available at http://www.jstor.org/page/info/about/policies/terms.jsp

JSTOR is a not-for-profit service that helps scholars, researchers, and students discover, use, and build upon a wide range of content in a trusted digital archive. We use information technology and tools to increase productivity and facilitate new forms of scholarship. For more information about JSTOR, please contact support@ jstor.org. 


\section{A DETERMINING FACTOR IN THE DEVELOPMENT OF ROMAN ARCHITECTURE.}

By Professor A. W. VAN BUREN.

It is of course universally recognised that Roman architects differed from their Greek or Hellenistic predecessors largely in the practice of spanning considerable spaces with arches, vaults or domes, whereas the Greeks limited themselves usually to stone architraves or wooden beams, with exceptional instances of the use of arches and probably simple trusses, of moderate dimensions. I am not certain, however, that it has occurred to investigators to discuss the possible cause for this radical difference between the two "classical" schools of architecture, except perhaps by generalisations as to racial qualities, merely another form of stating the same fact, rather than an explanation of it, or by reflections on the reckless waste of material and labour generated under a despotism, a form of explanation that will not carry conviction to the judicious. The matter is however of sufficient interest to justify the enquiry as to whether a more definite and convincing cause cannot be assigned.

This cause I believe to have been of a purely economic character. With regard to Greek architecture, much is to be said in favour of the view that most of the pecularities of both the Doric and the Ionic temples resulted from the translation into stone of structural and decorative forms which had originated in another material, walls of sun-dried brick and orders of wood; and there are also indications that while the Doric prototype used great wooden beams, the Ionic used planks and small rafters. This presupposes, for the earliest period, an abundance of wood available for building purposes. But it is in general demonstrable with a considerable degree of probability that at the period of the greatest development of the Greek cities large timbers were becoming more and more difficult and expensive to obtain; and the tendency, on economic grounds, was to use stone in preference to wood, at least for large buildings. This is of course meant only as a general statement : certain individual exceptions that may be adduced do not weaken its force. Thus, the Greek orders became literally petrified: Greek architecture is essentially an architecture of stone.

In Rome, however, conditions were different. The mere fact that the city was so frequently swept by conflagrations suggests the abundance of wood in the buildings; and this is confirmed by definite statements and implications in the authors. ${ }^{1}$ It is obvious

\footnotetext{
${ }^{1}$ See the references, and the discussion of them in Nissen, Italische Landeskunde, i, 429-436.
} 
that Augustus found Rome a city not only of sun-dried brick but also of wood, and it is reasonable to infer that it was, under existing conditions, more economical for the Romans to build of wood than of more durable materials. At the same time, with the practical engineering skill which they possessed, the ability to use wood freely would have led them to develop a system of trusses enabling them, even without the use of large timbers, to span greater spaces than the Greeks were accustomed to span. Thus we may assume that while wooden constructions were still economical the Romans became accustomed to availing themselves of large covered spaces. Then with the increasing cost of wood, which synchronised in general with a growing desire on their part for embellishing their cities with edifices of a more permanent and monumental character, they were gradually forced to choose between abandoning the spacious roofed interiors which had become an essential part of their life, and devising some other technical process for obtaining the same result. Given the serious issues involved, on the one hand, and their own practical training on the other, the outcome could not be long in doubt. There was to them nothing immutably fixed in the Greek canons of construction and proportion, and they were already acquainted with the use of arches and vaults on a small scale. The presence of excellent clay-beds and pozzolana-pits in the immediate neighbourhood of the city was of weight in deciding the materials and processes eventually to be preferred; the process of development was slow in reaching its culmination in the great imperial baths; but if the Romans in the first place had not become accustomed to wooden buildings which, because they were of wood, could disregard the restrictions imposed by the use of stone, they would have lacked the impulse to invention which resulted in their providing themselves with the means for eventually constructing the most striking architectural monuments of their civilisation.

Another peculiarity of Roman architecture, the steeper slope given to the pediment, in contrast to that of the Greek temple, is, I believe, to be explained by the use of wooden beams and trusses spanning wider spaces than the Greeks were accustomed to span, thus necessitating a sharper pitch to the roofs than was traditional in Greece. The statement in a recent manual ${ }^{\mathbf{1}}$ to the effect that trussed frames "can hardly have come into general use except with the steeper sloping roofs of the Romans," seems to me to invert the true sequence of cause and effect : the roofs would not have been made steeper until the introduction of trussed frames necessitated this.

I believe, moreover, that a striking characteristic of the Roman theatre and amphitheatre is due to the same cause. They were

${ }^{1}$ A. Marquand, Greek Architecture, $\mathbf{2}$. 


\section{I98 A FACTOR IN THE DEVELOPMENT OF ROMAN ARCHITECTURE.}

constructed free-standing, whereas the Greeks preferred to utilise rising ground for the purpose. Now we know that Pompey was the first to erect a permanent theatre in Rome. We have practically no information of a technical character as to the nature of the previous temporary structures; but I consider the origin of the characteristic Roman theatre to be most readily explained on the assumption that it is the rendering in stone of a type of structure which, in wood, was already familiar to the Romans, and had commended itself to them as possessing decided advantages. That for a long time Roman conservatism opposed the erection of a permanent structure is clear from the literary sources; and it is obvious that, for temporary theatres, the choice was either to occupy the slopes of the hills, with a subsidiary use of wooden scaffolding, or to construct freestanding theatres of wood. The former course may have been adopted for a time, or in connexion with certain festivals; but with the constant diminution of available space on the hillsides, and the increasing popularity of the Prata Flaminia and the Campus Martius for out-door life, the free-standing wooden theatre would naturally be evolved. And when the force of conservatism was weakening and at the same time the cost of wood was increasing and monumental structures were becoming more and more in vogue, it was, I believe, this type of theatre which the new architects reproduced in stone and concrete.

It goes without saying that other influences also were at work, climate, administrative requirements, and the like; also that the revenues at the disposal of the Romans were greater than those of their predecessors. But without the explanation which $I$ have suggested above, it would not be possible to understand why the great Hellenistic cities, Alexandria, Antioch, and Pergamon, populous, wealthy, and possessed of a very considerable development of civic life, but deprived of Rome's unique opportunities for obtaining an abundance of wood at a comparatively slight cost, should have failed to anticipate the characteristic architectural developments of the Romans.

It will be noted that the above observations do not touch the question as to the origin of the arch, vault and dome; they are concerned with a more important matter, namely the reasons for the adoption of these elements, on a grand scale, by imperial Rome, for the first time in the history of western civilisation. ${ }^{1}$

\footnotetext{
${ }^{1}$ It is a pleasure to acknowledge my obligation to Mr. G. P. Stevens, of the American Academy in Rome, for his kindness in giving me the benefit

of his architectural knowledge in discussing the above theory with me.
} 